\title{
Research on Teaching System Construction of Applied Surveying Engineering Specialty with "3S" as the Core
}

\author{
Liu Maohua, Shao Yue, Yao Jing, You Yingchun \\ School of Traffic Engineering, Shenyang Jianzhu University \\ Shenyang 110168, China
}

\begin{abstract}
In order to adapt to the application of surveying and mapping engineering specialty construction, by modifying the teaching plan, increase the content of the practice, appropriate cuts theoretical study, based on " $3 \mathrm{~S}$ " as the core of the practical teaching system construction surveying and mapping engineering major. In Shenyang Jianzhu University of surveying and mapping engineering applied transition, for example, from the theoretical teaching, practical teaching and examination method, faculty construction, etc, to develop new teaching plan and training system. The application of surveying and mapping engineering to increase the " $3 S$ " as the core of the teaching and practice content, both can meet the demand of cultivating application-oriented surveying and mapping engineering specialty teaching, and increase students' employment channels.
\end{abstract}

Keywords-application type; Major in surveying and mapping engineering; 3S; Teaching system

\section{INTRODUCTION}

Departments in November 2015, the ministry of education jointly issued "on the guiding parts of ordinary undergraduate course colleges and universities to practical guidelines" (here in after referred to as "opinions"), for part of the part of college professional pilot, transforming to be applied. To better promote these directly to the local and industry development in colleges and universities needs to cultivate talents, to better improve the learner's technology skills, quality of employment, entrepreneurship, and to lay the solid foundation for the longterm career development [1]. Shenyang architecture university of surveying and mapping engineering specialty is one of the Liaoning province education department to determine the second batch of pilot professional transformation, in accordance with the "opinions" requirement, to change the teaching plan of surveying and mapping engineering specialty in our school, joint training requirements, and connecting with the international certification system requirements, determine the "3S" as the core of the professional teaching system construction ideas.

\section{THE ORIGINAL TEACHING SYSTEM}

The surveying and mapping engineering major has a strong practical ability requirement, the opinion requires the practice

Liu Maohua (1981 - ), Liaoning Tieling people, associate professor, doctoral student, master tutor, the main research direction: mapping "3S" teaching and application.

2017 Education \&Teaching project of China Construction Education Association, ID: 2017077

Research on the establishment of undergraduate professional quality evaluation system, ID: JG15DB335 session to account for 30 percent, and the construction of application-oriented surveying and mapping should meet the professional requirements. At present, most university surveying and mapping engineering majors still follow the original teaching plan system, and the theoretical curriculum is complicated and complicated, and the theory and practice do not correspond to other problems [2]. It mainly includes:

- There are few practical links in theory teaching.

- There are many traditional measurements and few modern surveying and mapping content.

- Less external communication and more on-campus operation.

- The practice takes team assessment as the group and weakens individual performance appraisal.

To sum up, application-oriented surveying and mapping engineering majors must adapt to the development of modern surveying and mapping in the new period, and formulate scientific and reasonable teaching plan system according to the needs of modern surveying and mapping development in the new era.

\section{SET UP THE "3S" CORE TEACHING SYSTEM}

"3S" is the global satellite navigation system (GNSS), remote sensing (RS) and geographic information system (GIS), which is an important part of modern surveying and mapping[3]. At present, the industry of " $3 \mathrm{~S}$ " is booming, and the social demand is increasing. University surveying and mapping engineering is a major in the field of graduation, and in the service of traditional surveying and mapping industry, it should be more oriented to the demand of modern surveying and mapping industry [4]. Shenyang University of architecture surveying and mapping engineering major to take the transformation pilot as an opportunity, after careful deliberation, substantially revised the original teaching plan. When the total study time is unchanged, some theory courses are cut, new courses are added, the number of practice sessions is increased, and the theoretical and practical assessment methods are improved. 


\section{A. Theory and practice teaching reform}

Theory teaching should fully match the practice teaching, should not only focus on the related content and practice of teaching, and also to adjust the teaching schedule, and make the theory teaching progress and practice this course and other related courses matching; In terms of the theoretical teaching of the more intensive courses, the practical content and the learning time should be increased to ensure that the practical training courses account for more than $30 \%$ of the total class time, as shown in table 1: increase case teaching; To strengthen the construction of the practice base, all the internship should be completed in the internship base to enhance the effectiveness of the internship. To strengthen the cooperation with production units, the establishment of long-term cooperation mechanism, using the "go out, the introduction to" mode, choose some outstanding students, sent to the production units to production practice, at the same time to invite industry experts to exchange.

TABLE I. COMPARISON OF THEORETICAL TEACHING AND PRACTICE LINKS (PART)

\begin{tabular}{|c|c|c|c|c|c|}
\hline Course title & $\begin{array}{l}\text { Theoretical } \\
\text { time }\end{array}$ & $\begin{array}{l}\text { post } \\
\text { reform }\end{array}$ & Name of practice link & $\begin{array}{l}\text { Primary class } \\
\text { hours or weeks }\end{array}$ & $\begin{array}{l}\text { The number of live } \\
\text { weeks after the } \\
\text { reform }\end{array}$ \\
\hline $\begin{array}{l}\text { Fundamentals of } \\
\text { surveying and } \\
\text { mapping }\end{array}$ & 72 & 56 & $\begin{array}{l}\text { Basic experiment of } \\
\text { surveying and mapping }\end{array}$ & 24 & 32 \\
\hline Digitizing map & 64 & 40 & $\begin{array}{l}\text { Control the measurement } \\
\text { experiment }\end{array}$ & 16 & 24 \\
\hline Control surveying & 64 & 56 & $\begin{array}{l}\text { Experiment of GNSS } \\
\text { principle }\end{array}$ & 16 & 24 \\
\hline $\begin{array}{l}\text { Measurement of } \\
\text { adjustment basis }\end{array}$ & 80 & 64 & $\begin{array}{l}\text { Control surveying and } \\
\text { learning practice }\end{array}$ & 3 weeks & 4 weeks \\
\hline $\begin{array}{l}\text { Geological } \\
\text { geomorphology }\end{array}$ & 32 & 0 & $\begin{array}{l}\text { Internship in engineering } \\
\text { surveying }\end{array}$ & 3 weeks & 4 weeks \\
\hline $\begin{array}{l}\text { Introduction to } \\
\text { civil engineering }\end{array}$ & 32 & 0 & GIS course design & 0 & 1 week \\
\hline
\end{tabular}

The theory and practice of adding about "3S"

TABLE II. THE THEORY AND PRACTICE OF ADDING ABOUT "3S" ARE INCLUDED:

\begin{tabular}{cc}
\hline New curriculum and practice name & class hours \\
\hline GIS engineering design course & 24 \\
Remote sensing image interpretation & 32 \\
Introduction to modern surveying and mapping & 24 \\
Photogrammetry & 1 week \\
GIS course design & 1 week \\
"3S" comprehensive internship & 3 weeks \\
\hline
\end{tabular}

\section{B. Assessment method}

In the theoretical course, we will increase the score of the case analysis, and the case analysis can break through the limitation of the subject and focus on the students' ability to solve practical problems. In practice, the assessment of the quality of the team's results and the assessment of the ability of the individual, in all the internships, will increase the assessment of the ability of the individual. Improve the system of practice examination, in ordinary surveying course practice, for example, personal assessment full marks calculated at 100 points, the measurement time is 30 points, normative operation examination score is 20 points, record normative as 20 points, calculation of 30 points in the industry.
(1) The formula of measurement time score is:

$$
S_{i}=\left(1-\frac{T_{i}-T_{0}}{T_{n}-T_{0}} \times 0.4\right) \times 30
$$

In the formula, T0 is the shortest time, Tn is the longest time in the specified time, $\mathrm{Ti}$ is the completion time of the individual.

(2) Operational normalization: deducting points for nonconformity according to the measurement specifications.

(3) Record normality; Check the record form, which is deducted according to the scoring rules. 
(4) Internal computing: the measurement value is compared with the standard value, the limit is set, and the limit is deducted according to the scoring rules.

\section{Teaching staff construction scheme}

Application type transformation is a higher requirement for students' practical skills. As a teacher, teachers must start from themselves and improve their professional skills. In order to meet the requirements of teaching, on the other hand, requires teachers to improve self-quality, grasp the latest trends of the industry, strengthen the contact with production units, presents one's credentials the exercise may, when necessary, to the production unit, and regularly invite industry experts to check teacher training; On the other hand, the teacher's practice level is assessed and the teacher is urged to improve his skills. In addition, we will increase the team building of off-campus teachers, and use the internship base and the excellent talents of the cooperative units to communicate with each other regularly to ensure that the school teaching is closely related to the actual needs.

\section{Feedback system construction measures}

In order to adjust the training plan in time, we need to establish a perfect feedback system. On a regular basis to students, teachers, graduates and unit of choose and employ persons to carry on the discussion and review, collection and sorting after feedback, adjust and modify the training plan, to ensure the continuous improvement of students' quality.

From theory teaching, practice teaching, examination link and teacher training and so on positive research, supplemented by reverse feedback system research, to explore practical transformation pilot case teaching system construction of surveying and mapping engineering measures, this system construction thought is shown in figure 1 .

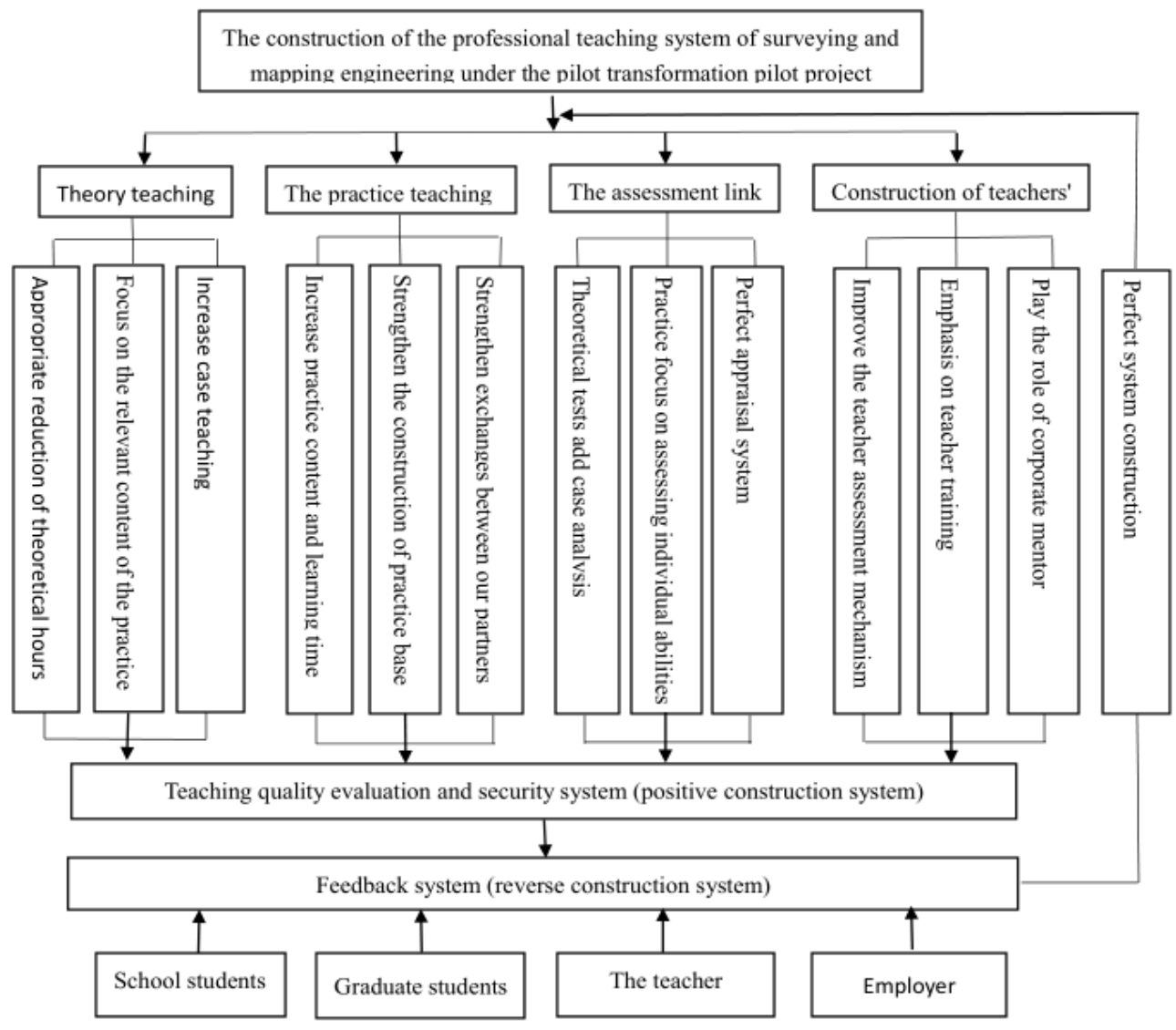

Fig. 1. The structure of the teaching system

\section{CONCLUSION}

According to the "Opinions" stipulation, the construction of the teaching system of the applied surveying and mapping engineering should be carried out in order to cultivate the students' technical application ability. From the aspects of theoretical teaching, practice teaching, examination and teacher training, the modern surveying and mapping "3S" Direction as the guide, to develop to adapt to the development of disciplines, to meet the employment needs of the teaching system for the construction of surveying and mapping engineering and employment services. 


\section{REFERENCES}

[1] Wang Yan, Liu Maohua, You Yingchun. Discussion on the training mode of students in surveying and mapping under the application - type transformation experiment [J]. Bulletin of Surveying and Mapping, 20161 (11): 144-147.

[2] Xiao Haiping, Chen Lanlan. Study on the teaching reform of surveying and mapping engineering under the registered surveying system [J]. Bulletin of Surveying and Mapping, 2012 (1): 108-110.

[3] Yang Keming, Shi Gangqiang, Wei Huafeng, et al. Research on the Training Mode of Informational Surveying Skills for Employment Needs [J]. Coal Higher Education, 2014, 32 (5): 106-109.
[4] He Liheng, Shi Yufeng, Zheng Jiazhu. The Construction of Practical Teaching System for Undergraduate Course of Surveying and Mapping Engineering [J]. Bulletin of Surveying and Mapping, 2010 (8): 74-76.

[5] WANG Qingguo, LIU Hanli,CHEN Wei, et al. Construction of the Integrated Instruction Contents for Science of Surveying and GIS[J]. Bulletin of Surveying and Mapping, 2016 (11): 141-143.

[6] JIANG Youyi. Teaching of GIS Course for Surveying and Mapping Engineering Specialty in Universities[J]. Technology and Innovation management, 2012,33(05):591-594. 